\title{
The Loyalty Model of Private University Student
}

\author{
Leonnard, Heny K.S Daryanto, Dadang Sukandar, Eva. Z. Yusuf \\ Institut Pertanian Bogor
}

\begin{tabular}{l} 
A R T I C L E I N F O \\
\hline Keywords: \\
student loyalty model, \\
service quality, \\
college image, \\
price, trust, \\
satisfaction, \\
structural equation model
\end{tabular}

Corresponding author:

leonnardong@gmail.com
A B S T R A C T

This study investigates Loyalty Model of Private University Student by using STIKOM London School of Public Relation as a study case. This study examined the model from service quality, college image, price, trust and satisfaction perspective. Thus, the objective of this study is to examine and analyze the effect of service quality, college image, tuition fee, trust and satisfaction towards students' loyalty; the effect of service quality, college image, price and satisfaction towards trust; and the effect of service quality, college image and price towards satisfaction. This study used survey methodology with causal design. The samples of the study are 320 college students. The gathering of data is conducted by using questionnaire in likert scale. The analysis of the data used a Structural Equation Model (SEM) approach. The implication of this study is portraying a full contextual description of loyalty model in private university by giving an integrated and innovated contribution to Student Loyalty Model in private university..

(C) 2014 IRJBS, All rights reserved.

\section{INTRODUCTION}

The fast development of globalization causes a more massive and competitive competition among individuals, groups, organizations and nations. Salomon (2013) satted that globalization makes the world seems more horizontal. The intensity of the competition is not only happening in business sector, but also in non business sector like non-profit organizations. This includes the education sector as well. As an illustration, there is a very fierce competition between public and private education institutions in Indonesia. The trigger of this phenomena is the fast growth of private universities. Up until now, there are 3.219 education institutions which consist of 99 public education institutions and 3.120 private education institutions organizing 10.680 programs in Indonesia (Pusat Data Kemendiknas, 2013). Out of those 3.120 private education institutions, around $13.9 \%$ (433) of them is university, $46.4 \%$ (1.446) is non-university (institute and college) and 39.7\% (1.240) of them is academy and polytechnic. This growth is very rapid, remembering in 2004, there were only 2.347 private education institutions in Indonesia. It means, within less than ten years, the growth of Indonesia's private education institutions is around $32.9 \%$. Ironically, the total number of student in Indonesia is only 5.616.670, consisting of 
1.816.390 public education institution students and 3.800.379 private education institutions student. By this token, it can be concluded that there are 18.346 students of public education institutions students and 1.218 students of private education institutions in average.

The total of private education institutions in DKI Jakarta is 317 institutions, which consists of: 14\%(45) universities, 44\% (139) institutes or college and 42\% (133) academy/polytechnic.This condition makes the private education institutions face a very hard challenge in getting students.

The condition is getting more competitive by the emerging existence of foreign university in Indonesia which is formally and legally permitted. Based on Undang-Undang Republik Indonesia Number 20 year 2003 about national education system, especially in article 65 , foreign education insitute which is already accredited in its country can operate its business in Indonesia. The other challenge faced by private education institutions is the application of Asean Economic Community in 1st January 2015. These regulations make it possible for foreign institutes to compete in Indonesia. If those foreign institutes are financially supported and having a good trust as well as good image, then this can become a serious threat and challenge for private institutions in Indonesia, especially in Jakarta.

This fierce competition urges private education institution to build a loyalty amongst the student so that the student can contribute back to the almamater. The tendency of building a loyalty model is also applied by STIKOM - London School of Public Relation Jakarta, which posesses one program of communication consisting of 5.121 undergraduate students and 353 graduate students. Since 1992, this institution has graduated 14.321 students, which consist of 13.551 undergraduate students and 770 graduate students (STIKOM LSPR, 2013). This institutions will be the object of this research. By observing the background and the existing problem, this study will be focusing on analyzing the positive effect of service quality, institution image, price, satisfaction and trust towards students loyalty.

The objectives of this research are: 1. Building and developing student loyalty model in private education institutions, which is influenced by service quality, institution image, price, satisfaction and trust integratedly. 2. Analyzing the positive effect of service quality, institution image, price and satisfaction towards student trust. 3. Analyzing the positive effect of service quality, institution image and price towards student satisfaction.

\section{Literature Review \\ Service Quality}

The service quality approach that is widely used on marketing research is developed and improved by Parasuraman et al; Zeithaml et al; (in Vinagre and Neves, 2008) known as SERVQUAL (service quality model). This approach is developed based on the comparison of two main factors, perceived perception and expected service. This model has 5 dimensions, as following tangibles, which is the appearance or physical facility, reliability which is the ability to give a promised service accurately, responsiveness which is the willingness to help the students and the ability to give a fast service, assurance which is knowledge of the lecturer, politeness and employees' ability to deliver information, empathy which is the degree of care and attention given to the students by the institution.

\section{Image}

Lopez et al (2011) summarize the definition of image based on several science disciplines, such as organizational behavior, psychology, sociology, strategic and marketing. Based on organizational behavior discipline, image is defined as individual perspective in contemplating his/her organization. Chattananon et al (2007) stated that corporate image has two main components, function and emotion. Function component related to intangible 
characteristic that can be easily measured, while emotion component related to psychology dimensions that can be manifested by evaluation, feeling, and attitude towards the corporation. To measure corporate image, several ways can be taken, one of them is by viewing its configuration element. Image element is aspects that become an object of corporate image. This image can also be the reference to measure corporate image. Based on Šmaižieno and Oržekauskas (2006), image has three main components:

a Visual element; this element relates to tangible organizational aspect. It includes organization style, lay out, brand, exterior, interior and so on

b Verbal element; this element relates to verbal information that can be exposed to consumer or shareholder, the examples are advertisement, public discussion, and so on

c Behavioral element; this element relates to management and output of certain organization. The examples are financial report, strategic position, product quality and management, corporate social responsibility and so on.

\section{Price}

In measuring consumers' perception towards fee or price that set by the producers, the price satisfaction dimensions developed by Matzler et al. (2006) can be used. It includes 5 dimensions, as following:

a Price transparancy, which is clear, comprehensive and relevant in setting the price according the recent situation. This dimension includes several aspects like a clear price information, completeness and accuracy.

b Price quality ratio, which is the comparation between service quality and monetary cost. This dimension is generated from comparing the product or service quality with the fee.

c Price relative, which is the offered price from the organization or the competitor.

d Price confidence, which is the assurance that the price is satisfying for the consumers. In other words, price is transparant and constantly low.

e Price reliability, which is the fulfillment of the expected or perceived price and the prevention of negative price shock. This relates to clear information regarding the price, no hidden price and a precise price change.

f Price fairness, which relates to consumers' perception whether the price difference between market price and competitor's price makes sense, acceptable and fair. This dimension relates to the correlation between price and social price, no abuse in price setting and no price discrimination.

\section{Satisfaction}

Vinagre and Neves (2008) used three dimensions to measure consumer satisfaction. The first dimension is expectation. Expectation is the focus of satisfaction literature investigation. In this case, satisfaction happens when product or service performance exceeds or at least same with consumer expectation. The second dimension is emotion, which is the set of response commonly happens during consumer experience. Consumer satisfaction in a higher extent involves positive and negative emotion. The third dimension is involvement. In consumerpsychology, involvement is a motivational construct that influences the set of consumer behavior. Although involvement is a complex construct, it is predicted that this can be seen when the service is congruent with service characteristic and consumer needs.

\section{Trust}

Robbins and Judge (2007) mentioned four key dimensions of trust concept, as following:

a. Integrity, which refers to honesty and righteousness

b. Competency, which relates to knowledge, technical and interpersonal skill possessed by an individual

c. Consistency, relates to reliability, predicting 
ability and individual evaluation in handling certain situation

d. Openness, according to DeVito (2001), openness refers to three interpersonal communication aspects, which are: willingness to revelation of self, as long as that revelation is adequate; willingness to be honest towards someone's opinion; having feelings and thoughts

Meanwhile, Mayer et al. (1995) and Rindings et al. (2002) (in Casalo et al., 2007) proposed that trust consist of three aspects, which are competence, honesty and benevolence.

\section{Loyalty}

A research from Beerli, Martin and Quintana (2004) which investigated about the loyalty in banking industry showed that consumer satisfaction is a significant factor in influencing the consumer loyalty. This research is also supported by a research from Martin-Consuerga, Molina and Esteban (2007) which showed that consumer satisfaction is significantly influencing loyalty. Espejel, Fandos and Flavian (2008) conducted a research about consumer satisfaction's key role in food industry and then analyzed this research using SEM showed that satisfaction has a significant effect towards loyalty.

Ndubisi (2009) proved that trust is a significant variabel in influencing loyalty. According to Hallowell (in Casalo et al, 2007 ) and Zeithaml (in Yu and Dean, 2001), there are four aspects can be used to measure loyalty. The first one is positive word of mouth. This positive communication can be in form of recommending to friends, telling positive things about the product and encouraging others to use the product. The second is complaint behavior. This is shown by complaining about the problem in using the product to the employee or the supervisor. The third one is switching behavior. This is shown by the effort to switch to other company's product, tempted by other company's offer and accepting other company's offer. The fourth one is willingness to pay more.

\section{METHODS \\ Research Design}

This study uses survey methodology with causal research design. Based on the minimum sample calculation proposed by Hair, et al (1995), the adequate samples for this study are 320 respondents consisting of 271 undergraduate and 49 graduate students. These samples are taken from the population of 1088 students at STIKOM LSPR which consists of 920 undergraduate and 168 graduate students. The sampling method used for this study is proportional random sampling technique which based on the study level and concentration determined by the random table.

\section{Data Collection}

A questionnaire is used as a data collection instrument. This questionnaire consists of 80 questions which are acquired from literature review. The questions in the questionnaire use 5 likert scale with 5 alternatives of answer : Very Agree (5), Agree (4), Uncertain (3), Disagree (2) and Very Disagree (1). Before being used in the actual study, this questionnaire was tested for its validity and reliability by using 30 samples.

\section{Data Processing and Analysis}

This study use Structural Equation Model (SEM) to carry out the confirmation analysis for the proposed loyalty model. SEM Analysis is conducted in order to enable testing the statistic model, as well as examining the cause and effect relationship among variables. As for the software, this study use LISREL 8.72.

\section{Relationships among Variables}

Path diagram, research hypothesis and relationships among variables can be portray by this picture 1 .

\section{RESULTS AND DISCUSSION \\ Respondent Profile}

The concentration of students participating in this 


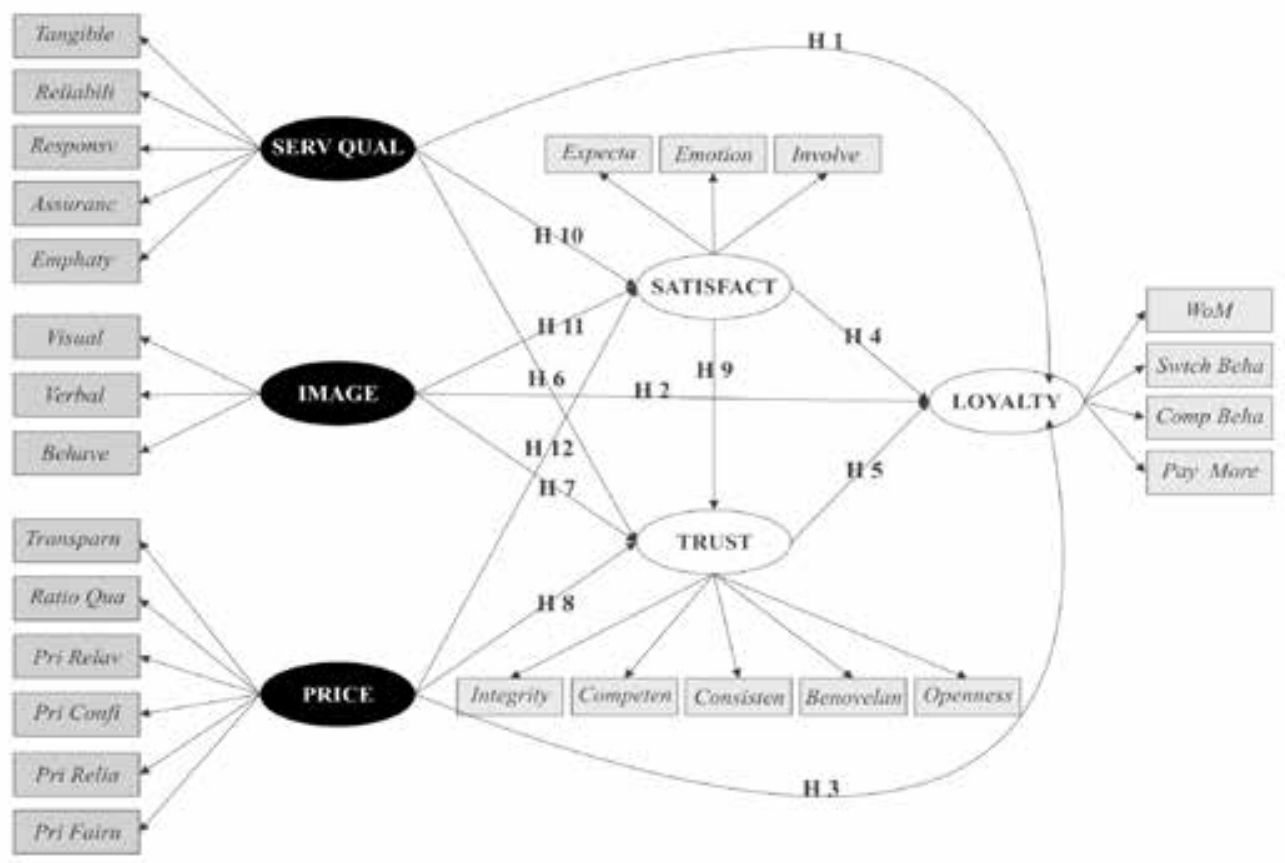

Picture 1. Path Diagram

study can be seen on table 1 and table 2 . All of the respondents are active students which consists of $85 \%$ (271 students) last year undergraduate (S1) and 15\% (49 students) graduate (S2).

Based on the gender, the majority of respondents participating in this study are female, which proportion is about 266 respondents or $83 \%$ of total respondent. As for the male respondent, there are 54 respondents or $17 \%$ of total respondent. Based on the age, most of the respondents are in their $20-23$, contributing $84 \%$ (269 respondents) of total respondent. As for the rest, 14\% (44 respondents) of them are between 20-23 years old. Geographically, it can be concluded that most of respondents resides in Jabodetabek area whereas 90\% of them are from Jabodetabek and 10\% of them are from Outer Java. As for the education history, most of the respondent comes from private and international high school, while the rest is from public high school. The proportion for students from private an public high school is $75 \%$ and $25 \%$ respectively. In terms of activeness, $70 \%$ students are active in non-campus activity, $25 \%$ are focusing in course and $5 \%$ are active on other activities. $90 \%$ of the students spend approximately 120 minutes/
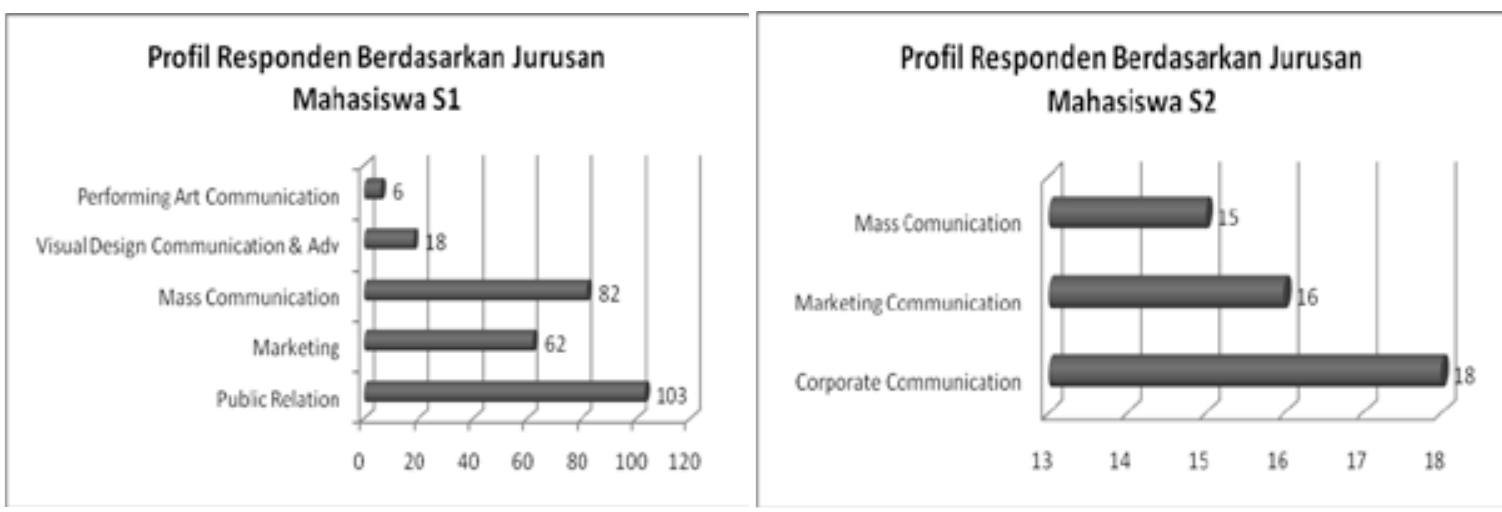
day for internet and social media, while the rest spend their time for internet and social media for 40 minutes/day. Based on the access to news and entertainment, $75 \%$ respondents prefer to access them from youtube while the rest prefer to access them from television.

\section{Descriptive Analysis}

Descriptive analysis is needed to examine respondents' answer on each variable. The result of descriptive analysis is in the form of average presented on the table. This result will be examined to see the tendency of respondents' answer in order to draw a conclusion. This study use the 5 likert scale categorization to give interpretation on respondents' answer, which range are from the lowest $1,2,3,4$ and 5 as the highest.

According to table 3, it can be concluded that service quality falls on high category of respondents' answer with 3.47 average points. As for the indicators of service quality, the highest average point among them is responsiveness with 3.60 , which also falls on high category. For image, the average point is 3.60 so it can be categorized in high category. All of image variable's indicators also fall on this category with behavior as the highest indicator, scoring 3.81 on average point. Meanwhile, for price variable, the average point is 3.52 or falls on high category. In this variable, price fairness indicator scores the highest average point with 3.77 , or in other words, included in high category.

For satisfaction variable, the average point falls on high category with 3.60 . While for its indicators, the highest average point is scored by expectation with 3.85. Trust variable has average point of 3.58 which makes it categorized as high category. As for its indicators, competency has the highest average point compared to others with 3.69 , and also falls on high category. For the last variable, loyalty, the average point is 3.49 and still becomes a part of high category. The highest average point of loyalty's indicator is 3.84 , which belongs to switching behavior.
The Relationship Analysis of Service Quality, Image, Price towards Satisfaction, Trust dan Loyalty

After conducting descriptive analysis for each variable, the next step taken is checking the existence of linier relationships among variables. This step also intends to examine the strength of the relationships. For this purpose, this study uses Spearman correlation by using SPSS 16.0 software as can be seen on Table 4 .

In terms of strength of correlation, the strongest correlation happens between price and loyalty with 0.594 point of correlation coefficient. This result shows that there is a positive correlation between price and student loyalty. As for the significance value, all correlation involving service quality to satisfaction, trust and loyalty is less than 0.05 (alpha $=5 \%)$. It means that the service quality provided by STIKOM London School of Public Relation correlates with satisfaction, trust and student loyalty.

Table 5 shows that there is a correlation between satisfaction, trust and loyalty. The correlation coefficient between student satisfaction and loyalty is 0.534 . It depicts that student satisfaction has a positive correlation with loyalty.

The result in Table 6 proves that there is a correlation between service quality and image with correlation coefficient of 0.573 . It can be concluded that there is a relatively strong correlation between these two variables. The bigger satisfaction of STIKOM London School of Public Relation will lead to the better image of that institution. The similar result is also applied on the correlation between service quality and price, with 0.578 point of correlation coefficient. As for the correlation between image and price, the coefficient is 0,547 .

\section{Structural Equation Model Analysis Reliability Analysis}

In Structural Equation Model, the measurement of reliability is using composite reliability 
Table 3. Average Point and Respondents' Answer Criteria

\begin{tabular}{clcc}
\hline No & \multicolumn{1}{c}{ Indicator } & Average & Criteria \\
\hline $\mathbf{1}$ & Tangible & 3,57 & High \\
$\mathbf{2}$ & Reliability & 3,51 & High \\
$\mathbf{3}$ & Responsiveness & 3,60 & High \\
$\mathbf{4}$ & Assurance & 3,41 & High \\
$\mathbf{5}$ & Emphaty & 3,23 & Adequate \\
& SERVICE QUALITY & 3,47 & High \\
$\mathbf{1}$ & Visual & 3,38 & Adequate \\
$\mathbf{2}$ & Verbal & 3,65 & High \\
$\mathbf{3}$ & Behavior & 3,81 & High \\
& IMAGE & $\mathbf{3 , 6 1}$ & High \\
$\mathbf{1}$ & Transparency & 3,65 & High \\
$\mathbf{2}$ & Ratio Quality & 3,55 & High \\
$\mathbf{3}$ & Price Relative & 3,12 & Adequate \\
$\mathbf{4}$ & Price Confidence & 3,59 & High \\
$\mathbf{5}$ & Price Reliability & 3,42 & High \\
$\mathbf{6}$ & Price Fairness & 3,77 & High \\
& PRICE & 3,52 & High \\
$\mathbf{1}$ & Expectation & 3,85 & High \\
$\mathbf{2}$ & Emotion & 3,64 & High \\
$\mathbf{3}$ & Involve & 3,30 & Adequate \\
& SATISFACTION & $\mathbf{3 , 6 0}$ & High \\
$\mathbf{1}$ & Integrity & 3,56 & High \\
$\mathbf{2}$ & Competency & 3,69 & High \\
$\mathbf{3}$ & Consistency & 3,64 & High \\
$\mathbf{4}$ & Benovelan & 3,66 & High \\
$\mathbf{5}$ & Openness & 3,34 & Adequate \\
& TRUST & $\mathbf{3 , 5 8}$ & High \\
$\mathbf{1}$ & Word of Mouth & 3,66 & High \\
$\mathbf{2}$ & Switching Behavior & 3,84 & High \\
$\mathbf{3}$ & Complaining Behavior & 3,23 & Adequate \\
$\mathbf{4}$ & Pay More & 3,22 & Adequate \\
& LOYALITY & $\mathbf{3 , 4 9}$ & High \\
\hline & & & \\
\hline
\end{tabular}

Table 4. Spearman Correlation of Service Quality, Image and Price toward Satisfaction, Trust and Loyality

\begin{tabular}{|c|c|c|c|c|}
\hline \multicolumn{2}{|c|}{ Spearman's rho } & \multirow{2}{*}{$\begin{array}{c}\text { SATISFACTION } \\
0,537^{* *}\end{array}$} & \multirow{2}{*}{$\begin{array}{c}\text { TRUST } \\
0,595^{* *}\end{array}$} & \multirow{2}{*}{$\begin{array}{c}\text { LOYALITY } \\
0,557 * *\end{array}$} \\
\hline SERVICE QUALITY & Correlation & & & \\
\hline & Coefficient & & & \\
\hline & Sig. (2-tailed) & 0,000 & 0,000 & 0,000 \\
\hline & $\mathrm{N}$ & 320 & 320 & 320 \\
\hline \multirow[t]{4}{*}{ IMAGE } & Correlation & $0,509^{* *}$ & $0,615^{* *}$ & $0,576 * *$ \\
\hline & Coefficient & & & \\
\hline & Sig. (2-tailed) & 0,000 & 0,000 & 0,000 \\
\hline & $\mathrm{N}$ & 320 & 320 & 320 \\
\hline \multirow[t]{4}{*}{ PRICE } & Correlation & $0,505^{* *}$ & $0,620 * *$ & $0,594 * *$ \\
\hline & Coefficient & & & \\
\hline & Sig. (2-tailed) & 0,000 & 0,000 & 0,000 \\
\hline & $\mathrm{N}$ & 320 & 320 & 320 \\
\hline
\end{tabular}


Table 5. Spearman Correlation of Satisfaction and Trust towards Loyality

\begin{tabular}{lcc}
\hline & Spearman's rho & LOYALITY \\
\hline SATISFACTION & Correlation Coefficient & $0.534^{* *}$ \\
& Sig. (2-tailed) & 0.000 \\
\multirow{2}{*}{ TRUST } & $\mathrm{N}$ & 320 \\
& Correlation Coefficient & $0.664^{* *}$ \\
& Sig. (2-tailed) & 0.000 \\
& $\mathrm{~N}$ & 320 \\
\hline
\end{tabular}

Table 6. Spearman Correlation of Service Quality, Image and Price

\begin{tabular}{cccc}
\hline \multicolumn{2}{c}{ Spearman's rho } & IMAGE & PRICE \\
\hline \multirow{2}{*}{ SERVICE QUALITY } & Correlation Coefficient & $0.573^{* *}$ & $0.578^{* *}$ \\
& $p$-value & 0.000 & 0.000 \\
\multirow{2}{*}{ IMAGE } & Correlation Coefficient & 1 & $0.547^{* *}$ \\
& $p$-value &. & 0.000 \\
\hline
\end{tabular}

measurement method and variance extracted measurement method. The analysis for the result is using measurement model, structural model and goodness of fit model (Wijanto, 2008). Measurement model analysis consists of the testing of construct reliability. As for model reliability, it can be measured using construct reliability, or by this formulation.

ConstructReliability $=\frac{\left(\sum \text { std. loading }\right)^{2}}{\left(\sum \text { std. loading }\right)^{2}+\sum e j}$

The analysis can be described by picture 2 .

As can be seen from the construct reliability calculation, the score for Service Quality is $\mathbf{0 , 8 7 7}$. This concludes that service quality variable has a good reliability because its construct reliability exceeds 0.7. According to Hair et al (2006), the requirement of a good reliability is when the construct reliability $(\mathrm{CR})>0.7$. Ghozali and Fuad (2005) also stated that reliability can be measured by construct reliability. As for the remaining variables, the construct reliability is as following: $\mathbf{0 . 8 3 5}$ for Image, $\mathbf{0 . 8 7 8}$ for Price, $\mathbf{0 , 7 9 2}$ for Satisfaction, 0.9 for Trust and 0.693 for Loyalty.

\section{Validity Analysis}

After conducting and obtaining the result of construct reliability, the next step is doing validity analysis. This step is taken right after conducting construct remodeling so that the result can be optimal. Based on the recommendation from Hair et al (2006), a proper observed variable used as an indicator of the construct or latent variable should have factor loadings which bigger than 0,5 or having a t-value bigger that its critical value $(>1.96)$

Based on the analysis of the average number of 26 statements describing the latent variabel, the t-value is obtained. This t-value of variables influencing Loyalty will be analyzed further by using LISREL software. From the output of t-value analysis, it can be concluded that all indicators have a t-value bigger than 1.96 , or valid. The validity is also guaranteed by standardized solution value. Based on standardized solution value, for Service Quality, the main indicator is reliability with $\mathbf{0 . 8 5}$. For Image, the main indicator is Behavior with 0.85. As for Price, the main indicator is Price Reliability with $\mathbf{0 . 8 2}$. For Satisfaction, the main indicator is Expectation with 0.77. While for Trust, the main indicator is Competency with 0.84 . For 


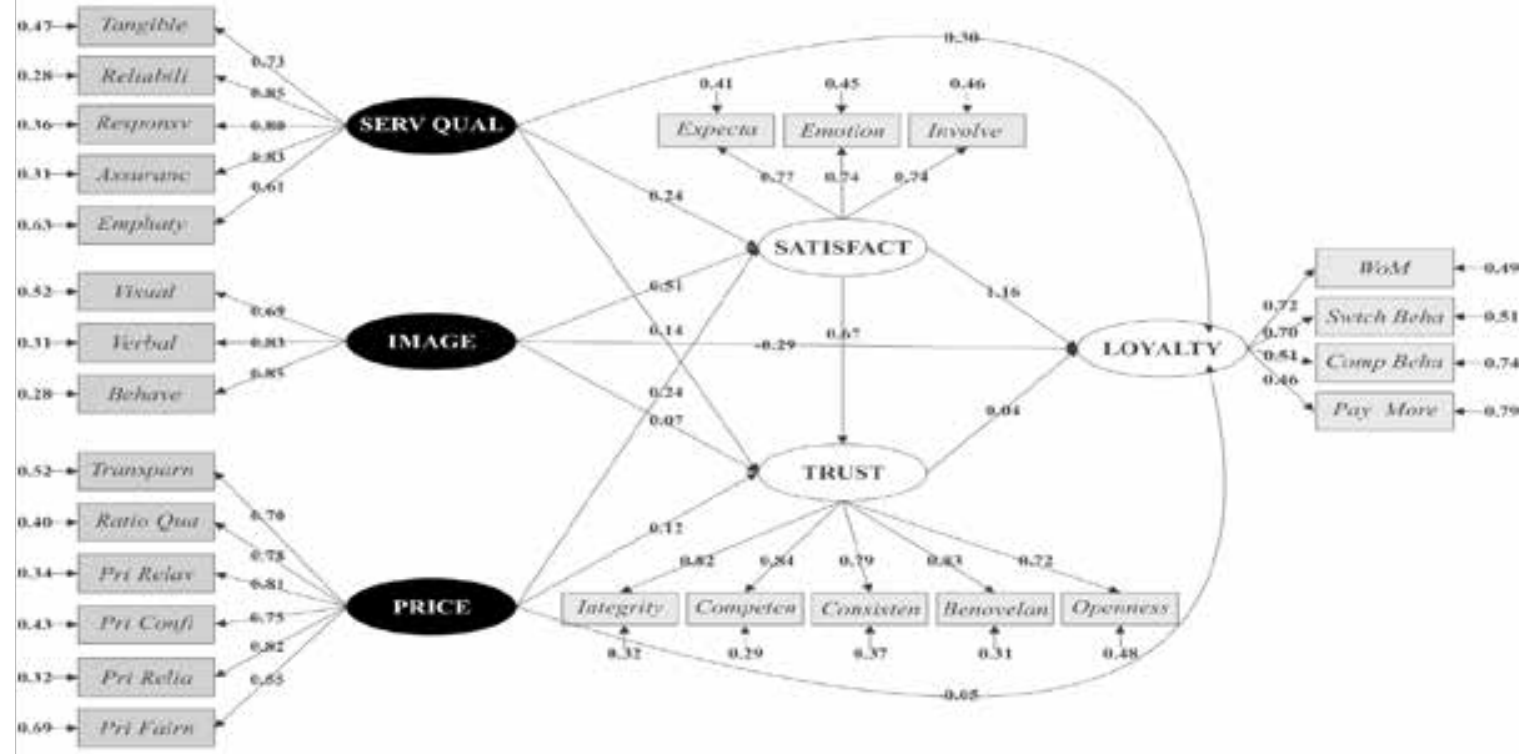

Picture 2. Output of Standardized Solution test

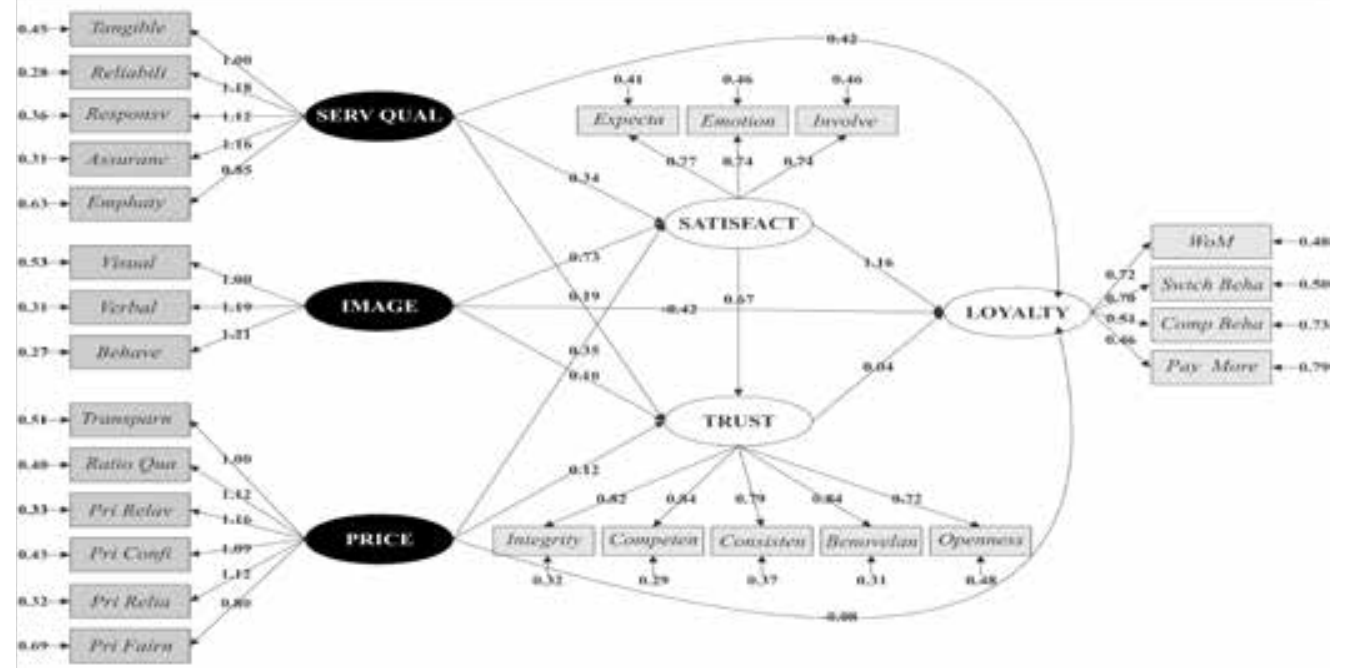

Picture 3. Output of Estimates Analysis

Loyalty as the last variable, the main indicator is Word of Mouth with $\mathbf{0 . 7 2}$.

\section{Analysis of Model Goodness of Fit and Structural Model}

The result of this analysis is also used as research hypothesis testing. The statistical testing for these structural model causal hypotheses is using a $5 \%$ level of significance or $\pm 1,96$ critical t-value. The first step of data analysis in Structural Equation Model is testing the goodness of fit of the model by using LISREL 8.72 software. Ho will be accepted if P-value exceeds 0.05 or if RMSEA is less than 0.08 . For this study, $\mathrm{P}$-value $=0$ and RMSEA $=0.058$. Referring on the required criteria from Joreskog, et al (1996), then the empirical model of this study can be accepted. The result of this analysis can be seen on picture 3 .

As for the t value, all of them show the relationship that is in accordance with research framework. These can be seen on Picture 4. 


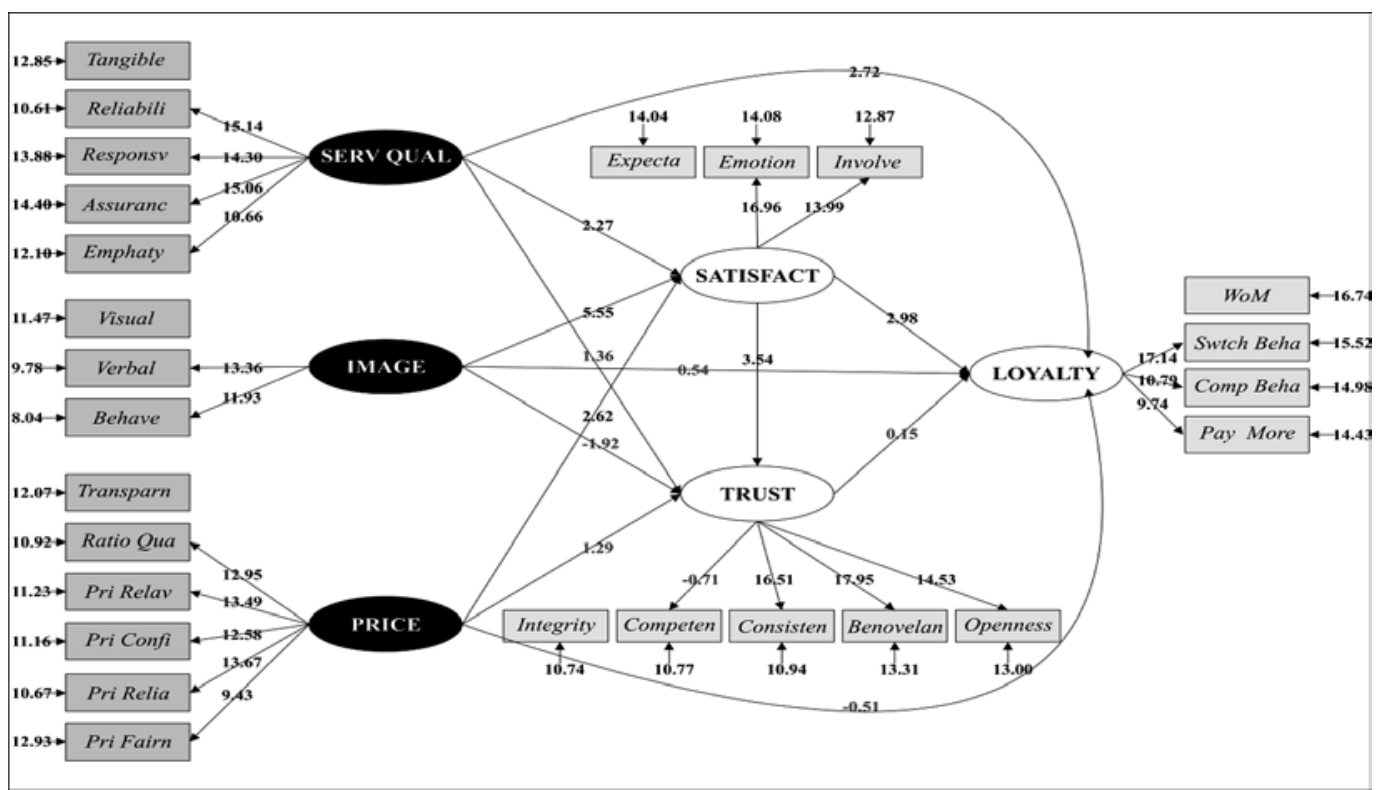

Picture 4. $\mathrm{t}$-Value Testing of Structural Model

Table 7. Evaluation of structural model coefficient

\begin{tabular}{cccccl}
\hline Hypotheses & Path & Standardized & t-value & t-tabel & Conclusion \\
H1.1 & ServQual $->$ Satisfact & 0.24 & 2.27 & 1.96 & Significant \\
H1.2 & ServQual $->$ Trust & 0.14 & 1.36 & 1.96 & Not Significant \\
H1.3 & ServQual $->$ Loyality & 0.30 & 2.72 & 1.96 & Significant \\
H1.4 & Image $->$ Satisfact & 0.51 & 5.55 & 1.96 & Significant \\
H1.5 & Image $->$ Trust & 0.07 & -1.92 & 1.96 & Not Significant \\
H1.6 & Image $->$ Loyality & -0.29 & 0.54 & 1.96 & Not Significant \\
H1.7 & Price $->$ Satisfact & 0.24 & 2.62 & 1.96 & Significant \\
H1.8 & Price $->$ Trust & 0.12 & 1.29 & 1.96 & Not Significant \\
H1.9 & Price $->$ Loyality & -0.05 & -0.51 & 1.96 & Not Significant \\
H1.10 & Satisfact $->$ Loyality & 1.16 & 2.98 & 1.96 & Significant \\
H1.11 & Satisfact $->$ Trust & 0.67 & 3.54 & 1.96 & Significant \\
H1.12 & Trust $->$ Loyality & 0.04 & 0.15 & 1.96 & Not Significant \\
\hline
\end{tabular}

The evaluation of structural model coefficient as well as its interrelation with hypotheses can be described in table 7 .

\section{MANAGERIAL IMPLICATION}

Some of these managerial implication can be implemented by the management of higher education institution, especially for the management of STIKOM London School of Public Relation:
1. Referring to descriptive analysis, although the service quality is pretty high, it is still on the adequate category. A lot of improvements should be taken in order to increase the service quality. The improvements should be prioritized on the medium value aspects, like amenity of the empoyee, a clear and easy to be comprehended information, employee's openness towards the students, the fulfillment of students' right to get academic service 
and the comfort of classroom. Therefore, the management has to be able to properly in order to be able to give a high quality service. The amenity can be improved by encouraging employees to always greet and smile to the students. The employees also need to be provided with communication training in order to be able to communcate effectively with the student. Another effort that should be taken is auditing the facilities in the campus, whereas the improper ones should be replaced. The management also has to ensure the fulfillment of students' right, especially the ones related to the academic service.

2. Referring to descriptive analysis, although the institution image is high, it tends to be on the adequate category. A lot of improvements should be taken in order to improve the institution image. The improvement should prioritize the medium point aspect, like campus building and campus exterior design. Related to this matter, the management needs to re-evaluate the appeal of its building. Management can conduct a survey for employees and students in order to acquire their opinion regarding the physical appearance of the campus. If there is a feedback that the campus needs to be renovated, then the management has to do the planning to change campus appearance with accordance to higher education institution architecture.

3. Referring to descriptive analysis, although the tuition fee's score is high, it tends to be on the adequate category. Therefore, an improvement on the tuition fee policy is needed. The first priority of the improvement is the one related to accessibility, acceptability a clear reasoning of tuition fee escalation. Related to this issue, campus management needs to evaluate their policy regarding the tuition fee, whether it is affordable for the student or not. If it is indeed not affordable for the student, then campus management needs to do a deeper analysis by comparing its fee with other equivalent institutions. Another evaluation is whether the tuition fee reflects the education quality. These consideration needs to be evaluated thoroughly in order to obtain an appropriate decision: either to decrease its tuition fee or to increase its education quality. Campus management also has to be transparent in giving argumentation for the raise of tuition fee. The timing for this raise also needs to be considered.

\section{Theoritical Suggestion}

Theoritical sugestions that can be contributed by this study are:

1. For the next study, a bigger sample size and a wider coverage area is needed. This requirement will enable the study be generalized into a wider scope.

2. For the next study, it is suggested to use another analysis methodology like Partial Least Square (PLS) and Generalized Structured Component Analysis (GSCA).

\section{CONCLUSION}

1. Service quality has a significant effect on the loyalty of STIKOM London School of Public Relation students. This result shows that a quality service will lead to the increasing student loyalty.

2. Image of higher education institution has a significant effect on the loyalty of STIKOM London School of Public Relation students. This finding indicates that a good image of the institution can significantly induce students to be loyal.

3. Price does not have a significant effect on the loyalty of STIKOM London School of Public Relation students. This finding imply that tuition fee will not significantly increase student loyalty.

4. Satisfaction has a significant effect on on the loyalty of STIKOM London School of Public 
Relation students. This result shows that a high level of satisfaction will lead to the high level of student loyalty.

5. Trust does not have a significant effect on the loyalty of STIKOM London School of Public Relation students. By this finding, it can be concluded that trust does not have the role in determining the level of student loyalty

6. Service quality does not have a significant effect on the trust of STIKOM London School of Public Relation students. This means that a high quality service will not give direct impact on the escalation of student trust.

7. Higher education institution image does not have a significant effect on the trust of STIKOM London School of Public Relation students. This finding indicates that a positive image of higher education institution will not give impact on the escalation of student trust

8. Price does not have a significant effect on the trust of STIKOM London School of Public Relation students. This result shows that fee does not always influence the trust of student
9. Satisfaction has a significant effect on the trust of STIKOM London School of Public Relation students. This result indicates that high satisfaction will lead on a better trust from the student.

10. Service quality has a significant effect on the satisfaction of STIKOM London School of Public Relation students. This finding shows that a high service quality will increase student satisfaction.

11. Higher education institution image has a significant effect on the satisfaction of STIKOM London School of Public Relation students. This means that positive image of higher education institution will increase student satisfaction.

12. Price has a significant effect on the satisfaction of STIKOM London School of Public Relation students. It means that if the Price is already set according the proper principal, it will increase the satisfaction of the student.

\section{REFEREN CES}

Aaker DA, Kumar V, George S. (2004). Marketing Research. Ed ke-8. New York (US): John Wiley \& Sons.

Akbar MM, Parvez N. (2009). Impact of Service Quality, Trust, and Customer Satisfaction on Customer Loyalty. ABAC Journal. 29(1):24-38

Alves H, Raposo M. (2010). The Influence of University Image on Student Behavior. International Journal of Educational Management. 24(1):73 - 85 .

Andreassen TW. (2000). Antecedents to Satisfaction with Service Recovery. European Journal of Marketing. 34(1):156-175.

Arbuckle JL, Wothke W. (1999). Amos 4.0 User's Guide. Chicago (US) : Small Water Corporation.

Azwar S. 2003. Reliabilitas dan Validitas. Yogyakarta (ID): Pustaka Pelajar.

[APTISI] Asosiasi Perguruan Tinggi Swasta Indonesia. (2013). Data Sekunder Perguruan Tinggi Swasta. Jakarta (ID): APTISI.

Barnes JG. (2001). Secrets of Customer Relationship Management: it's all About How you Make Them Feel. New York (US): Mc Graw Hill.

Beerli A, Mart $I n$ JD, Quintana A. (2004). A Model of Customer Loyalty in The Retail Banking Market. European Journal of Marketing. 38(2):253-275.

Bloemer J, Ruyter KD. (1999). Customer Loyalty in High and Low Involvement Settings: The Moderating Impact of Positive Emotions. Journal of Marketing Management. 15(4):315-30.

Brunner TA, Stocklin M, Opwis K. (2008). Satisfaction, Image and Loyalty: New versus Experienced Customers. European Journal of Marketing. 42(10):1095-1105.

Caruana A. (2002). Service Loyalty: The Effects of Service Quality and The Mediating Role of Customer Satisfaction. European Journal of Marketing. 36(8):811-828. 
Casalo L, Flavian C, Guinaliu M. (2007). The Impact of Participation in Virtual Brand Communities on Consumer Trust and Loyalty: The Case of Free Software. Journal Online Information Review. 31(6):775-792.

Chattananon A, Jirasek ML, Numchai T, Leelayouthayothin SL. (2007). Building Corporate Image Through Societal Marketing Programs. Journal Society and Business Review. 2(3):230-253.

Chen C. (2006). Identifying Significant Factors Influencing Consumer Trust In An Online Travel Site. Journal Information Technology \& Tourism. 8(1):197-214.

Cronbach J, Mechl PE. (1955). Construct Validity in Psychological Test. New York (US): Psychological Bulletin.

Decker TJ. (2006). Exploring E-Customers and The Relational Effects of Satisfaction, Trust and Commitment [Dissertation]. Florida (US): Nova Southeastern University.

DeVito JA. (2001). Komunikasi Antar Manusia. Jakarta (ID): Professional Books.

DiRusso DJ. (2010). An Examination of Price Dispersion In an Online Retail Marketplace [Dissertation]. Pennsylvania (US): The Temple University.

Eklof, Cassel. (2001). Marketing. New York (ID): Prentice Hall.

Espejel J, Fandos C, Flavian C. 2008. Consumer Satisfaction: A Key Factor of Consumer Loyalty and Buying Intention of a PDO Food Product. British Food Journal. 110(9):865-881.

Flavian C, Guinaliu M. 2005. The Influence of Corporate Image on Consumer Trust: A Comparative Analysis in Traditional versus Internet Banking. Journal Internet Research. 15(4):447-470.

Gaspersz V. (2002). Total Quality Management. Jakarta (ID): PT. Gramedia Pustaka Utama.

Gefen D. (2002). Customer Loyalty in E-Commerce. Journal of the Association for Information Systems. 3:27-51.

Ghozali I, Fuad. (2005). Structural Equation Modeling: Teori, Konsep, dan Aplikasi dengan Program LISREL 8.54. Semarang (ID): Badan Penerbit UNDIP.

Gibson JL, Ivancevich JM, Donnely JA. (1992). Fundamentals of Management. Boston (US) : Irwin.

Gronroos C. (2001). The Perceived Service Quality Concept - a Mistake?. Journal of Managing Service Quality. 11(3):150-152.

Hadi S. (2002). Metodologi Research 2. Yogyakarta (ID): Yayasan Penerbitan Fakultas Psikologi Universitas Gajah Mada.

Hair JF, Anderson RE, Tatham RE, Black WC. (1995). Multivariate Data Analysis with Readings. New Jersey (US): Prentice Hall.

Hair JF, Anderson RE, Tatham RE, Black WC. (1998). Multivariate Data Analysis with Readings. New Jersey (US): Prentice Hall.

Hair JF, Anderson RE, Tatham RE, Black WC. (2006). Multivariate Data Analysis. Ed ke-6. New Jersey (US): Prentice Hall.

Hair JF, Anderson RE, Tatham RE, Black WC. (2010). Multivariate Data Analysis. Ed ke-7 New Jersey (US): Pearson Education.

Hampshire S. (2007). Customer Satisfaction, Loyalty and Profit: Understanding The Links Between Service dan The Bottom Line [Internet]. [download 2012, Feb 13]. www.saterfak.com.

Johnson MD, Gustafson A, Andreassen TW, Lervik L, Cha J. (2000). The Evolution and Future of National Customer Satisfaction Index Models. Journal of Economic Psychology. 22(2):1-43.

Johnson MD, Gustafson A. (2000). Improving Customer Satisfaction Loyalty and Profit. University of Michigan (US): Business School Management Series.

Joreskog KG, Sorbom D. (1989). LISREL 7 : User's Reference Guide. Mooresville (US): Scientific Software.

Joreskog KG, Sorbom D. (1996). LISREL 8: Structural Equation Modeling with the SIMPLIS Command Language. Chicago (US): Scientific Software International.

Joreskog KG, Sorbom D, Toit SD, Toit MD. (1999). LISREL 8: New Statistical Features. Chicago (US): Scientific Software International.

Kotler P. (2003). Marketing Management. New Jersey (US): Prentice Hall.

Kotler P, Armstrong G. (1997). Marketing an Introduction. New Jersey (US): Prentice Hall International.

Lopez C, Gotsi M, Andriopoulos C. (2011). Conceptualising The Influence of Corporate Image on Country Image. European Journal of Marketing. 45(12):1601-1641.

Lovelock C. (1994). Product Plus:How to Product + Service Competitive Advantage. New York (US): Mc Graw Hill.

Mao Y. (2008). Destination Image Building and Its Influence on Destination Preference and Loyalty of Chinese Tourists to Australia [Dissertation]. Kowloon (HK): The Hong Kong Polytechnic University.

Matzler K, Wurtele A, Renzl B. (2006). Dimensions of Price Satisfaction: a Study in The Retail Banking Industry. International Journal of Bank Marketing. 24(4):216-231.

Mayer RC, Davis JH, Schoorman FD. (1995). An Integratif Model of Organizational Trust. Journal Academy of Management Review. 20(3):709-734.

Mollering G. (2006). Trust: Reason, Routine, Reflexivity. Oxford (BG): Elsevier.

Morgan RM, Hunt. (1994). Relationship Marketing in The Era of Network Competition. Journal of Marketing Management. 3(1):18. 
Ndubisi NO. (2007). Relationship Marketing and Customer Loyalty. Journal Marketing Intelligence \& Planning. 25(1):98-106.

Nugroho A. (2010). Analisis Keterkaitan Antara Kepuasan Proses Belajar Mengajar, Citra dan Loyalitas di Perguruan Tinggi [Dissertation]. Bogor (ID): Institut Pertanian Bogor.

Oliver RL. (1999). Whence Customer Loyalty? Journal of Marketing. 63(4):33.

Padma P, Rajendran C, Lokachari PS. (2010). Service Quality And Its Impact On Customer Satisfaction In Indian Hospitals: Perspectives Of Patients And Their Attendants. Benchmarking: An International Journal. 17(6):807-841.

Parasuraman A, Zeithaml VA, Berry LL. 1997. Delivering Quality Srvice, Balancing Customer Perceptions and Expectations. New York (ID): Mc Graw Hill.

Pemerintah Republik Indonesia. (2003). Undang-undang Republik Indonesia Nomor 20 Tahun 2003 tentang Sistem Pendidikan Nasional. Jakarta (ID): Sekretariat Negara.

Pusat Data Informasi Perguruan Tinggi. 2013. Laporan Jumlah Perguruan Tinggi. Jakarta (ID): Kementerian Pendidikan.

Robbins SP, Judge TA. (2007). Organizational Behavior. New York (US) : Prentice-Hall Jersey.

Rojas-Mendez JI, Kara AZVA, Cerda-Urrutia A. (2009). Determinants of Student Loyalty in Higher Education: A Tested Relationship Approach in Latin America. Journal Latin American Business Review. 10(1):21-39.

Salomon MR, Tuten TL. (2013). Social Media Marketing. New York (US): John Wiley and Sons.

Saunders M, Lewis P, Thornhill A. (2009). Research Methods for Business Students. Essex (US) : Pearson Education Limited.

Schwarze JA. (2000). A Model To Forecast The Effect Of Price Changes On Brand Loyalty of Non Durable, Consumer Packaged Goods In A Competitive Environment [Dissertation]. Florida (US): University of Sarasota.

Sekolah Tinggi Ilmu Komunikasi London School Public Relation. (2013). Booklet Promotion. Jakarta (ID): STIKOM LSPR.

Sirdeshmusk JSD. (2010). Agency and Trust Mechanism in Consumer Satisfaction and Loyalty Judgment. Journal of the Academy of Marketing Science. 28(1):150-167.

Smaizieno I, Orzekauskas P. (2006). Corporate Image Audit. Journal of Management. 1(10).

Soemirat S, Ardianto E. (2003). Dasar-dasar Public Relations. Bandung (ID): PT Remaja Rosdakarya.

Sugiyono. (2004). Metode Penelitian Bisnis. Bandung (ID): Alfabeta.

Sutisna. (2002). Perilaku Konsumen dan Komunikasi Pemasaran. Jakarta (ID): PT Remaja Rosdakarya.

Tharenou P, Donohue R, Cooper B. (2007). Management Research Methods. Cambridge (BG): Cambridge University Press.

Thompson A. (2007). Customer Satisfaction in 7 Steps [Internet]. [download 2012, Feb 18]. http://www.sitepoint. com/article/ satisfaction-7-steps.

Toelle S. (2006). The Linkages Among Service Quality Attributes, Customer Value, Customer Satisfaction and Customer Loyalty In Indonesian Retail Banking Settings [Dissertation]. Florida (US): Nova Southeastern University.

Trasorras RJ. (2008). The Relationship of Value, Satisfaction and Loyalty on Customer Retention in the Professional Service Sector [Dissertation]. Florida (US): Nova Southeastern University.

Usman H, Akbar PS. (2008). Metodologi Penelitian Sosial. Jakarta (ID): PT Bumi Aksara.

Vinagre MH, Neves J. (2008). The Influence of Service Quality and Patients' Emotions on Satisfaction. International Journal of Health Care Quality Assurance. 21(1):87-103.

Virvilaite R, Saladiene V, Skindaras D. (2009). The Relationship between Price and Loyalty in Services Industry. Journal Inzinerine Ekonomika-Engineering Economics. (3):96-104.

Wijanto SH. (2008). Stuctural Equation Model dengan Lisrell 8.8 Konsep dan Tutorial. Jakarta (ID): Graha Ilmu.

Wijaya T. (2009). Analisis Structural Equation Modeling Menggunakan AMOS. Yogyakarta (ID): Universitas Atma Jaya Yogyakarta.

Williams C, Bueswell J. (2003). Service Quality in Leisure and Tourism. Cambridge (BG): CABI Publishing.

Yieh K, Chiao Y, Chiu Y. (2007). Understanding the Antecedents to Customer Loyalty by Applying Structural Equation Modeling. Journal Total Quality Management . 18(3):267-284.

Yu C, Chang H, Huang G. (2006). A Study of Service Quality, Customer Satisfaction and Loyalty in Taiwanese Leisure Industry. Journal of American Academy of Business. 9 (1).

Yu Y, Dean A. (2001). The Contribution of Emotional Satisfaction to Customer Loyalty. International Journal of Service Industry Management. 12(3):234 - 250 .

Zeithaml VA, Bitner MJ. (2003). Service Marketing: Integrating Customer Focus Across the Firm. New York (US): Mc Graw Hill. 